\title{
Relationship of Supplement Intake Behavior to Performance and Grazing Behavior of Cattle Grazing Mixed-Grass Rangelands
}

\author{
Samuel A. Wyffels (Corresponding author) \\ Northern Agricultural Research Center, Montana State University \\ 3710 Assinniboine Road, Havre, MT 59501, United States \\ Tel: 1-541-805-5792Ｅ-mail: samwyffels@montana.edu
}

Julia M. Dafoe

Northern Agricultural Research Center, Montana State University

3710 Assinniboine Road, Havre, MT 59501, United States

Tel: 1-406-265-6115Ｅ-mail: jdafoe@montana.edu

\section{Cory T. Parsons}

Northern Agricultural Research Center, Montana State University 3710 Assinniboine Road, Havre, MT 59501, United States

Tel: 1-541-403-0042Ｅ-mail: cory.parsons@student.montana.edu

Darrin L. Boss

Northern Agricultural Research Center, Montana State University

3710 Assinniboine Road, Havre, MT 59501, United States

Tel: 1-406-265-6115_E-mail: dboss@montana.edu

Timothy DelCurto

Dept. of Animal and Range Sciences, Montana State University

PO Box 172900, Bozeman, MT 59717, United States

Tel: 1-406-994-3708 E-mail: timothy.delcurto@montana.edu 


\section{MlMacrothink}

Received: February 19, 2021

doi:10.5296/jas.v9i2.18425
Journal of Agricultural Studies

ISSN 2166-0379

2021, Vol. 9, No. 2

Accepted: March 15, $2021 \quad$ Published: March 17, 2021

URL: https://doi.org/10.5296/jas.v9i2.18425

\begin{abstract}
This study evaluated the relationships between supplement intake behavior, beef cattle performance, and grazing behavior on dormant northern mixed-grass rangelands. In each of two years, a commercial herd of bred cows grazed a rangeland pasture from November to January. All cattle were managed as one contemporary group. Calf birth date, birth weight, and adjusted 205-day weaning weight were collected for each cow following the grazing season each year as cow performance metrics. During the grazing season, all cattle were provided free-choice access to a self-fed supplement. Supplement intake behavior was measured for each individual. Grazing behavior was monitored for 30 randomly selected individuals. The relationship of individual average daily supplement intake $(R=0.65 ; \rho=$ $0.65)$, supplement consumption rate $(R=0.58 ; \rho=0.54)$, the coefficient of variation of supplement intake $(R=0.51 ; \rho=0.50)$, and the amount of time spent at the feeder $(R=0.47$; $\rho=0.49)$ were positively correlated and ranked across years $(P<0.01)$, suggesting individual animal supplement intake behavior is repeatable for cattle grazing dormant season rangelands. Additionally, there were multiple significant associations between supplement intake behavior, cattle performance, and grazing behavior $(P \leq 0.05)$; however, the majority were weak associations that accounted for minimal variation in cattle performance and grazing behavior $\left(R \leq 0.27 ; r^{2} \leq 0.07\right)$. Although supplement intake behavioral traits were repeatable across years, its use as a metric to predict animal performance and grazing behavior may be limited.
\end{abstract}

Keywords: beef cattle, cattle performance, dormant season grazing, grazing behavior, supplementation

\title{
1. Introduction
}

Beef cattle temperament has become an increasingly important factor in herd management as it can directly impact average daily gain, feed conversion efficiency, and carcass quality characteristics of feedlot cattle, reflected in the overall economic return to the beef cattle producer (Voisinet et al. 1997, Cafe et al. 2011, Goodman et al. 2016). However, the same beef cattle temperaments negatively correlated to feedlot performance appear to be unrelated to grazing behavior and animal performance on rangelands (Fordyce et al. 1988, Bailey et al. 2010, Reeves and Derner 2015). Thus, the effect of temperament on beef cattle performance is likely mediated by confinement and human interaction (Reeves and Derner 2015, Goodman et al. 2016). Additionally, recent research suggests that evaluating a single behavioral trait to determine an animal's overall temperament or evaluating temperament traits relevant to confinement when determining effects of temperament on grazing behavior may not produce meaningful results (Wesley et al. 2012, Goodman et al. 2016). Therefore, it has been proposed that animal behavioral traits consistent from animal to animal and across time (behavioral syndromes) be used when evaluating the effects of behavior and 
temperament on grazing cattle performance (Sih et al. 2004, Wesley et al. 2012, Goodman et al. 2016). From an ecological perspective, behavioral syndromes can limit an individual's ability to adapt to fluctuating environmental conditions, thereby impacting animal fitness (Bell 2007, Smith and Blumstein 2008). Thus, studying individual variation in correlated behavior syndromes could provide valuable means of explaining animal to animal productivity differences in rangeland settings (Wesley et al. 2012).

Seasonal deficiencies in rangeland forage quality often require supplementation to maintain animal performance and provide increased economic returns, however, the reported effectiveness of supplementation programs on grazing cattle performance has been inconsistent, likely due to variation in supplement intake behavior by individual cows (Bowman and Sowell 1997, DelCurto et al. 2000). Recent research evaluating the correlation of behavioral traits to grazing beef cattle performance using the behavioral syndrome framework has demonstrated that cattle exhibiting rapid rates of supplement consumption have higher weight gains, heavier calf weaning weights, and travel farther than their counterparts with slow supplement consumption rates (Wesley et al. 2012). Although this study is unique in its adaptation of the behavioral syndrome framework to a livestock production system, behavioral traits were only measured for thirty-six individuals (18 per year) and the supplement was administered unconventionally (individually hand-fed supplement in confinement, bi-weekly). Thus, little is known about the repeatability and effects of supplement intake behavior on grazing beef cattle performance in more conventional production scenarios. Therefore, the specific objectives of this research were to 1) evaluate the repeatability of individual animal supplement intake behavior across multiple years and 2) determine the relationships between supplement intake behavior, performance, and grazing behavior by beef cattle offered a self-fed protein supplement during dormant season grazing.

\section{Method}

The use of animals in this study was approved by the Agricultural Animal Care and Use Committee of Montana State University (\#2015-AA04). A commercial herd of bred cows (Angus, Angus $\times$ Simmental) ranging in age from $1-12$-yr-old grazed on a 329-ha rangeland pasture $\left(\sim 1.2 \mathrm{ha} \cdot \mathrm{AUM}^{-1}\right)$ for two consecutive years (272 cows in the 1st year, and 302 cows in the 2nd year). All cattle within each year were managed as one contemporary group, where females were synchronized and timed artificially inseminated in early June 2016 and 2017. Cattle were exposed to cover bulls for an additional 45 days of natural service post-artificial insemination. Calves were weaned in early fall (mid-September to mid-October). After the dormant grazing season, subsequent calf birth date, birth weight, and adjusted 205-day weaning weight were collected for each cow in both years of the study as measurements of cow performance. The dormant grazing season in which supplement intake behavior was measured occurred from December 1, 2016 to January 12, 2017, and November 1, 2017 to December 31, 2017. Cattle were weighed, and body condition scored at the initiation and completion of the grazing trial. All cattle had free-choice access to a $30 \%$ crude protein self-fed canola meal-based pelleted supplement with $25 \%$ salt to limit intake (Table 1). The target daily intake was $0.91 \mathrm{~kg} \cdot \mathrm{cow}^{-1}$. Each animal was equipped with an electronic ID tag 


\section{Macrothink}

Journal of Agricultural Studies

ISSN 2166-0379

2021, Vol. 9, No. 2

(Allflex USA, Inc., Dallas-Ft. Worth, TX) attached to the left ear for the measurement of individual supplement intake $\left(\mathrm{g} \cdot \mathrm{d}^{-1}\right)$, supplement consumption rate $\left(\mathrm{g} \cdot \mathrm{min}^{-1}\right)$, time spent at the supplement feeder $\left(\min \cdot \mathrm{d}^{-1}\right)$, and the coefficient of variation for supplement intake $(\%)$ using a SmartFeed Pro self-feeder system (C-Lock Inc., Rapid City, SD) which provided a total of 8 feeding stations. Grazing activity was monitored for 30 randomly selected individuals each year with Lotek GPS collars ( $\mathrm{n}=60$; 3300LR; Lotek Engineering, Newmarket, Ontario, Canada) containing head position sensors that record timing and location of grazing activities (Turner et al. 2000, Ungar et al. 2005, Brosh et al. 2010). Each collar was configured to record GPS positions at 15-minute intervals and head position, vertical/horizontal movements at 5-minute intervals. Grazing activity was separated from non-grazing activities using the binary classification methods developed by Augustine and Derner (2013) to examine time spent grazing $\left(\mathrm{hr} \cdot \mathrm{d}^{-1}\right)$. Distance traveled $\left(\mathrm{km} \cdot \mathrm{d}^{-1}\right)$ was measured as the distance moved between GPS fixes in a day.

Table 1. Supplement composition for cattle winter grazing rangeland in $2016 \& 2017$ at the Thackeray ranch, Havre MT (as-fed basis)

\begin{tabular}{lc}
\hline $\mathrm{CP}^{1}$ & $30.00 \%$ \\
Crude fat & $1.00 \%$ \\
Crude fiber & $8.00 \%$ \\
Ca & $2.00 \%$ \\
P & $1.00 \%$ \\
Salt & $25.00 \%$ \\
K & $0.75 \%$ \\
Se & $1.5 \mathrm{ppm}^{2} \%$ \\
Vitamin A & $9,072 \mathrm{IU} \cdot \mathrm{kg}^{-1}$ \\
Vitamin D & $907 \mathrm{IU} \cdot \mathrm{kg}^{-1}$ \\
Vitamin E & $9 \mathrm{IU} \cdot \mathrm{kg}^{-1}$ \\
\hline $19.9 \%$ non-protein N &
\end{tabular}

Dormant season grazing occurred at the Thackeray Ranch ( $\left.48^{\circ} 21^{\prime} \mathrm{N} 109^{\circ} 30^{\prime} \mathrm{W}\right)$, part of the Montana Agricultural Experiment Station located 21-km south of Havre, MT, Hill county USA. Climate is characterized as a semi-arid steppe with an average annual precipitation of 
$410 \mathrm{~mm}$. Vegetation is dominated by Kentucky bluegrass (Poa pratensis L.), bluebunch wheatgrass (Pseudoregnaria spicata [Pursh] A. Love), and rough fescue (Festuca scabrella Torr.).

The repeatability of individual supplement intake behavior across years was evaluated using Pearson product-moment and Spearman rank correlation tests for individuals present in both years of the study $(n=226)$. In addition, the relationship between supplement intake behavior, performance, and grazing behavior was evaluated using a Pearson product-moment and a Spearman rank correlation test to determine if supplement intake behavior, performance, and grazing behavior are correlated or ranked animals in a similar order. An alpha $\leq 0.05$ was considered a significant relationship, and tendencies were considered at $P \leq 0.10$. All data were analyzed in R (R Core Team 2017).

\section{Results}

Minimum, mean, and maximum values for all supplement intake behavioral traits, performance, and grazing behavior metrics for each year are presented in Table 2. Individual average daily supplement intake $(R=0.65 ; \rho=0.65)$, supplement consumption rate $(R=0.58$; $\rho=0.54)$, the coefficient of variation of supplement intake $(R=0.51 ; \rho=0.50)$, and the amount of time spent at the feeder $(R=0.47 ; \rho=0.49)$ were both positively correlated and ranked animals similarly across years $(P<0.01$; Figure 1$)$. Thus, individual animal supplement intake behavior is repeatable for cattle grazing dormant season rangelands.

Table 2. Minimum, mean, and maximum values for supplement intake behavioral traits, performance, and grazing behavior metrics for cattle winter grazing rangeland in 2016 \& 2017 at the Thackeray ranch, Havre MT

\begin{tabular}{cccccc}
\multicolumn{3}{c}{ Year 1 } & & \multicolumn{2}{c}{ Year 2 } \\
\cline { 1 - 1 } & Mean $\quad$ Max. & & Min. Mean Max
\end{tabular}

Supplement Intake Behavior traits

$\begin{array}{lrrrrrr}\text { Average Intake, } \mathrm{g} \cdot \mathrm{d}^{-1} & 0.05 & 1.72 & 4.14 & 0.11 & 1.87 & 4.08 \\ \text { Supplement Intake Rate, } \mathrm{g} \cdot \mathrm{min}^{-1} & 58.23 & 293.36 & 432.89 & 81.79 & 282.32 & 398.12 \\ & & & & & & \\ \text { Intake CV, \% } & 30.78 & 76.67 & 191.62 & 42.33 & 69.35 & 175.22 \\ \text { Time Spent at Feeder, } \mathrm{min} \cdot \mathrm{d}^{-1} & 0.44 & 5.80 & 13.07 & 0.72 & 6.75 & 19.44\end{array}$

Performance and Grazing Behavior

Calf Birth Date

$\begin{array}{llllll}56.00 & 80.00 & 121.00 & 58.00 & 80.00 & 122.00\end{array}$ 
Calf Birth Wt, kg

Calf Weaning Wt, kg

Change in Cow Wt, kg

Change in Cow BCS

Distance Traveled, $\mathrm{km} \cdot \mathrm{d}^{-1}$

Time Spent Grazing, $h r \cdot d^{-1}$
27.44

101.7

$-108.86$

$-47.66$

$-1.25$

0.12

1.00

$-1.25$

$-0.18$

0.75

2.52

3.30

4.16

2.10

3.30

4.44

2.69

4.35

6.46

1.98

4.22

6.52

*Year $1 \mathrm{n}=245 ;$ Year $2 \mathrm{n}=276$
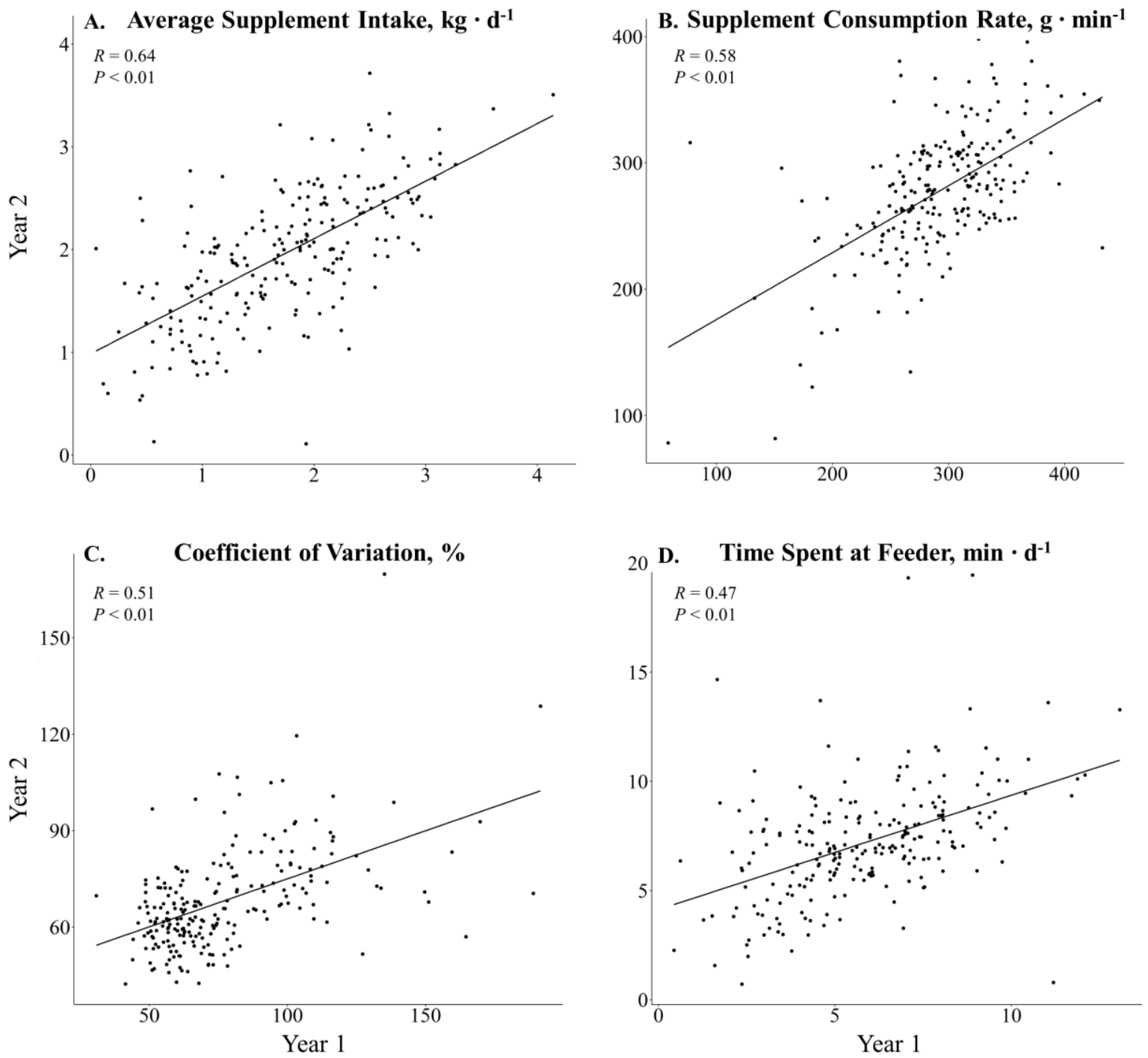
Figure 1. The repeatability (linear regression) of supplement intake behavior for A. supplement intake $\left(\mathrm{g} \cdot \mathrm{d}^{-1}\right)$, B. supplement consumption rate $\left(\mathrm{g} \cdot \mathrm{min}^{-1}\right)$, C. coefficient of variation of supplement intake $(\%)$, and $\mathrm{D}$. time spent at the feeder $\left(\mathrm{min} \cdot \mathrm{d}^{-1}\right)$ of individual cattle present during both the $2016 \& 2017$ dormant grazing season $(n=226)$

Average daily supplement intake and time spent at the feeder were not correlated to beef cattle performance nor grazing behavior $(P \geq 0.11$; Table $3 \& 4)$. Supplement consumption rate was negatively associated and ranked with calving date $(R=-0.10 ; \rho=-0.10 ; P \leq 0.03)$. Additionally, supplement consumption rate and calf birth weight were negatively ranked $(\rho=$ -0.10; $P=0.02$ ), indicating that cattle with rapid supplement consumption rates are more likely to calve earlier in the year and have lighter birth weight calves. Supplement consumption rate was positively associated and ranked with a change in body condition $(R=$ $0.10 ; \rho=0.11 ; P \leq 0.02)$, where cattle with rapid supplement consumption rates were more likely to have a positive change in body condition while grazing dormant forage. Supplement consumption rate ranked cattle similarly to distance traveled per day $(\rho=0.28 ; P=0.04)$ and tended to be positively associated $(R=0.25, P=0.07)$. In addition, time spent grazing tended to be negatively associated and ranked with supplement consumption rate $(R=-0.23 ; \rho=$ $-0.25 ; P \geq 0.07)$. Thus, as supplement consumption rates increase, cattle traveled further and spent less time grazing.

Table 3. Pearson correlation coefficients for pair-wise associations between supplement intake behavioral traits, performance and grazing behavior for cattle winter grazing rangeland in 2016 \& 2017 at the Thackeray ranch, Havre MT

\begin{tabular}{lcccc}
\hline & $\begin{array}{c}\text { Average } \\
\text { Intake, } \\
\text { g } \cdot \mathrm{d}^{-1}\end{array}$ & $\begin{array}{c}\text { Supplement } \\
\text { Intake Rate, } \\
\mathrm{g} \cdot \mathrm{min}^{-1}\end{array}$ & $\begin{array}{c}\text { Intake } \\
\mathrm{CV}, \%\end{array}$ & $\begin{array}{c}\text { Time Spent at } \\
\text { Feeder, } \\
\mathrm{min} \cdot \mathrm{d}^{-1}\end{array}$ \\
\hline Calf Birth Date & -0.04 & $-0.10^{*}$ & $0.08^{\dagger}$ & 0.02 \\
Calf Birth Wt, kg & 0.02 & -0.05 & 0.06 & 0.04 \\
Calf Weaning Wt, $\mathrm{kg}$ & -0.04 & $<0.01$ & $0.13^{* *}$ & -0.03 \\
Change in Cow Wt, $\mathrm{kg}$ & 0.06 & 0.03 & $-0.13^{* *}$ & 0.05 \\
Change in Cow BCS ${ }^{1}$ & 0.03 & $0.10^{*}$ & 0.02 & -0.03 \\
Distance Traveled, $\mathrm{km} \cdot \mathrm{d}^{-1}$ & 0.16 & $0.25^{\dagger}$ & $-0.27^{*}$ & 0.04 \\
Time Spent Grazing, hr $\cdot \mathrm{d}^{-1}$ & -0.21 & $-0.23^{\dagger}$ & -0.09 & -0.12 \\
\hline
\end{tabular}

${ }^{1} P$-values were not adjusted for multiple comparisons 
* Significant associations $P \leq 0.05$

** Significant associations $P \leq 0.01$

${ }^{\dagger}$ Associations $P \leq 0.10$

${ }^{2}$ Body condition score on a $1-9$ scale

Table 4. Spearman correlation coefficients for pair-wise associations between supplement intake behavioral traits, performance, and grazing behavior for cattle winter grazing rangeland in 2016 \& 2017 at the Thackeray ranch, Havre MT

\begin{tabular}{lcccc}
\hline & $\begin{array}{c}\text { Average } \\
\text { Intake, } \\
\mathrm{g} \cdot \mathrm{d}^{-1}\end{array}$ & $\begin{array}{c}\text { Supplement } \\
\text { Intake Rate, } \\
\mathrm{g} \cdot \mathrm{min}^{-1}\end{array}$ & $\begin{array}{c}\text { Intake } \\
\mathrm{CV}, \%\end{array}$ & $\begin{array}{c}\text { Time Spent at } \\
\text { Feeder, } \\
\mathrm{min} \cdot \mathrm{d}^{-1}\end{array}$ \\
\hline Calf Birth Date & -0.10 & $-0.10^{*}$ & 0.06 & 0.04 \\
Calf Birth Wt, $\mathrm{kg}$ & 0.01 & $-0.10^{*}$ & $0.13^{* *}$ & 0.03 \\
Calf Weaning Wt, $\mathrm{kg}$ & -0.05 & $<0.01$ & $0.11^{* *}$ & -0.04 \\
Change in Cow Wt, $\mathrm{kg}$ & 0.07 & 0.01 & $-0.12^{* *}$ & 0.07 \\
Change in Cow BCS & 0.05 & $0.11^{* *}$ & $<0.01$ & -0.02 \\
Distance Traveled, $\mathrm{km} \cdot \mathrm{d}^{-1}$ & 0.19 & $0.28^{*}$ & -0.17 & 0.05 \\
Time Spent Grazing, hr $\cdot \mathrm{d}^{-1}$ & -0.16 & $-0.25^{\dagger}$ & -0.08 & -0.07 \\
\hline
\end{tabular}

${ }^{1} P$-values were not adjusted for multiple comparisons

* Significant associations $P \leq 0.05$

** Significant associations $P \leq 0.01$

${ }^{\dagger}$ Associations $P \leq 0.10$

${ }^{2}$ Body condition score on a $1-9$ scale

Variation in supplement intake ranked individuals similarly to calf birth weight $(\rho=0.13 ; P<$ $0.01)$. Additionally, the variation of supplement intake had a positive association and was ranked similarly with calf weaning weights $(R=0.13 ; \rho=0.11 ; P \leq 0.01)$. Variation in supplement intake also tended to be positively associated with calf birth date $(R=0.08, P=$ 0.08). Thus, cattle with higher levels of variation in supplement intake are more likely to calve later and have calves with higher birth and weaning weights. However, supplement 
intake CV was negatively associated and ranked with cow body weight change while grazing dormant rangelands $(R=-0.13 ; \rho=-0.12 ; P<0.01)$. Distance traveled per day was also negatively associated with variation in supplement intake $(R=-0.27 ; P=0.05)$. Thus, cattle with high levels of variation in supplement intake tended to lose more weight and travel less per day when grazing dormant season rangelands.

\section{Discussion}

Our findings suggest that supplement intake behavior can be repeatable for individuals across years. Additionally, supplement intake behavior can have significant associations with animal performance; however, it accounts for minimal variation. Previous literature evaluating the relationships between supplement intake behavior, grazing behavior, and beef cattle performance has found cattle that rapidly consume supplements are more likely to distribute on the landscape and perform better in weight gains and reproductive efficiency (Wesley et al. 2012). Our results contradict these previous findings as we found no significant relationship between supplement consumption rate and cow weight gains and a negative association with calf birth weight. Additionally, our results suggest that cattle with high supplement consumption rates traveled further per day and tended to decrease time spent grazing. Providing protein supplement to cattle grazing dormant forage often results in reduced time spent grazing (Krysl and Hess 1993, Schauer et al. 2005) as cattle either increase grazing intensity and harvest efficiency or consume supplement as a substitute to forage (Barton et al. 1992, Krysl and Hess 1993, Moore et al. 1995). Despite the significant relationships in our results, the supplement intake consumption rate explained minimal variation in animal performance and grazing behavior $\left(r^{2} \leq 0.06\right)$. Although our results contradict research by Wesley and coworkers (2012), differences may be due to our study's supplement delivery system. Specifically, we measured supplement intake behavior with a free-choice self-fed supplement feeder $a b$ libitum rather than hand-feeding a controlled amount of supplement to individual cows in confinement bi-weekly.

Our results also suggest that variation in supplement intake $(\% \mathrm{CV})$ is positively associated with calf birth weight and weaning weight; however, negatively associated with distance traveled and cow weight change while grazing dormant forage. Supplementation strategies assume that all animals consume a target quantity of supplement, and deviation from the target intake can have deleterious effects on animal performance reflected as weight gains (Bowman and Sowell, 1997). Additionally, the variation of daily supplement intake has been shown to increase with the age of cattle grazing in winter rangeland environments (Wyffels et al. 2020). Therefore, the observed relationships between variation in supplement intake and calf birth and weaning weights could be related to cow age and associated cow age influences on supplement intake behavior. However, data are limited relative to the relationship between cow variation in supplement intake and calf production. The lack of information is related to the difficulty in measuring the intake of free-choice supplements in extensive production environments (DelCurto and Olson, 2010). Although our study detected associations between variation in supplement intake and calf birth and weaning weights, variation in supplement intake accounted for minimal variation in cow performance $\left(r^{2}=0.02\right)$, suggesting these associations may not be meaningful for cattle management. 


\section{Conclusion}

Evaluating behavioral traits that may serve as metrics to predict beef cattle's suitability in limited nutritional environments could be useful to the western livestock industry. Results from our research suggest supplement intake behavioral traits may be repeatable across years; however, their use as a metric to predict animal performance and grazing behavior is limited. Due to the inconsistent results relating supplement intake to cattle performance, future research should consider evaluating the association of supplement intake behavior to cattle performance across multiple nutrient delivery systems and diverse grazing environments.

\section{Acknowledgments}

This material is based upon work that is supported by Montana's Agricultural Experiment Station and the National Institute of Food and Agriculture, US Department of Agriculture, under award number 2015-38640-23779 through the Western Sustainable Agriculture Research and Education program under sub-award number (GW17-040). Appreciation is also expressed to the Nancy Cameron Endowment, the Bair Ranch Foundation, the Montana Stock Growers Association for research funding, and the MSU Northern Agricultural Research Center employees for their assistance with this project. USDA is an equal opportunity employer and service provider.

\section{References}

Augustine, D. J., \& Derner, J. D. (2013). Assessing herbivore foraging behavior with GPS collars in a semiarid grassland. Sensors (Basel), 13(3), 3711-323. https://doi.org/10.3390/s130303711

Bailey, D., VanWagoner, H., Jensen, D., Boss, D., \& Thomas, M. (2010). Relationship of temperament at calving and distribution of beef cows grazing foothill rangeland. Proc. West. Sec. Anim. Sci., 61, 109-112.

Barton, R. K., Krysl, L. J., Judkins, M. B., Holcombe, D. W., Broesder, J. T., Gunter, S. A., \& Beam, S. W. (1992). Time of daily supplementation for steers grazing dormant intermediate wheatgrass pasture. $J$ Anim Sci., 70, 547-558. https://doi.org/10.2527/1992.702547x

Bell, A. M. (2007). Evolutionary biology: animal personalities. Nature, 447, 539-540. https://doi.org/10.1038/447539a

Bowman, J. G., \& Sowell, B. F. (1997). Delivery method and supplement consumption by grazing ruminants: a review. J. Anim. Sci., 75, 543-550. https://doi.org/10.2527/1997.752543x

Brosh, A., Henkin, Z., Ungar, E. D., Dolev, A., Shabtay, Orlov, A., ... Aharoni, Y. (2010). Energy cost of activities and locomotion of grazing cows: a repeated study in larger plots. $J$. Anim. Sci., 88, 315-323. https://doi.org/10.2527/jas.2009-2108

Cafe, L., Robinson, D., Ferguson, D., McIntyre, B., Geesink, G., \& Greenwood, P. (2011). Cattle temperament: persistence of assessments and associations with productivity, efficiency, 
carcass and meat quality traits. J. Anim. Sci., 89, 1452-1465. https://doi.org/10.2527/jas.2010-3304

DelCurto, T., B. Hess, J. Huston, \& K. Olson. (2000). Optimum supplementation strategies for beef cattle consuming low-quality roughages in the western United States. J. Anim. Sci., 77, 1-16. https://doi.org/10.2527/jas2000.77e-suppl1v

DelCurto, T., Olson, K., Hess, B. W., Bowman, J. G., \& Waterman, R. C. (2010). Issues in grazing livestock nutrition. In Proc. $4^{\text {th }}$ Grazing Livestock Nutrition Conference, Western Section American Society of Animal Science, 1-10.

Fordyce, G., Dodt, R., \& Wythes, J. (1988). Cattle temperaments in extensive beef herds in northern Queensland. 1. Factors affecting temperament. Aust. J. Exp. Agric., 28, 683-687. https://doi.org/10.1071/EA9880683

Goodman, L. E., Cibils, A. F., Wesley, R. L., Mulliniks, J. T., Petersen, M. K., Scholljegerdes, E. J., \& Cox, S. H. J. R. (2016). Temperament affects rangeland use patterns and reproductive performance of beef cows. Rangelands, 38, 292-296. https://doi.org/10.1016/j.rala.2016.07.002

Krysl, L. J., \& Hess, B. W. (1993). Influence of supplementation on behavior of grazing cattle. J Anim Sci., 71, 2546-2555. https://doi.org/10.2527/1993.7192546x

Moore, J., Bowman, J., \& Kunkle, W. (1995). Effects of dry and liquid supplements on forage utilization by cattle. Proc. AFIA Liquid Feed Symposium, 81-95.

R Core Team. (2017). R: A language and environment for statistical computing. R Foundation for Statistical Computing: Vienna, Austria. Available at: http://www.R-project.org/

Reeves, J. L., \& Derner, J. D. (2015). Temperament does not affect steer weight gains on extensively managed semiarid rangeland. Rangelands, 37, 186-190. https://doi.org/10.1016/j.rala.2015.07.004

Schauer, C. S., Bohnert, D. W., Ganskopp, D. C., Richards, C. J., \& Falck, S. J. (2005). Influence of protein supplementation frequency on cows consuming low-quality forage: performance, grazing behavior, and variation in supplement intake. J Anim Sci., 83, 1715-1725. https://doi.org/10.2527/2005.8371715x

Sih, A., Bell, A. M., Johnson, J. C., \& Ziemba, R. E. (2004). Behavioral syndromes: an integrative overview. Q. Rev. Biol., 79, 241-277. https://doi.org/10.1086/422893

Smith, B. R., \& Blumstein, D. T. (2008). Fitness consequences of personality: a meta-analysis. Behav. Ecol., 19, 448-455. https://doi.org/10.1093/beheco/arm144

Turner, L., Udal, M. , Larson, B., \& Shearer, S. (2000). Monitoring cattle behavior and pasture use with GPS and GIS. Can. J. Anim. Sci., 80, 405-413. https://doi.org/10.4141/A99-093 


\section{Macrothink}

Journal of Agricultural Studies

ISSN 2166-0379 2021, Vol. 9, No. 2

Ungar, E. D., Henkin, Z., Gutman, M., Dolev, A., Genizi, A., \& Ganskopp, D. (2005). Inference of animal activity from GPS collar data on free-ranging cattle. Rangel. Ecol. Manag., 58, 256-266. https://doi.org/10.2111/1551-5028(2005)58[256:IOAAFG]2.0.CO;2

Voisinet, B., Grandin, T., Tatum, J., O'connor, S., \& Struthers, J. (1997). Feedlot cattle with calm temperaments have higher average daily gains than cattle with excitable temperaments. J. Anim. Sci., 75, 892-896. https://doi.org/10.2527/1997.754892x

Wesley, R. L., Cibils, A. F., Mulliniks, J. T., Pollak, Petersen, M. K., \& Fredrickson, E. L. (2012). An assessment of behavioural syndromes in rangeland-raised beef cattle. Appl. Anim. Behav. Sci., 139, 183-194. https://doi.org/10.1016/j.applanim.2012.04.005

Wyffels, S. A., Dafoe, J. M., Parsons, C. T., Boss, D. L., DelCurto, T., \& Bowman, J. G. (2020). The influence of age and environmental conditions on supplement intake by beef cattle winter grazing northern mixed-grass rangelands. $J$ Anim Sci., 98, skaa217. https://doi.org/10.1093/jas/skaa217

\section{Copyright Disclaimer}

Copyright for this article is retained by the author(s), with first publication rights granted to the journal.

This is an open-access article distributed under the terms and conditions of the Creative Commons Attribution license (http://creativecommons.org/licenses/by/4.0/). 